\title{
The Model of Performance Information System For A Private University
}

\author{
Heni Nurani $\mathbf{H}^{\mathbf{1}}$, Dian Indiyati ${ }^{2}$ and Ifan Wicaksana Siregar ${ }^{3}$ \\ \{heni.nurani@lecture.unjani.ac.id ${ }^{1}$ \} \\ 1,2,3 Universitas Jenderal Achmad Yani, Cimahi, Indonesia
}

\begin{abstract}
This study aims to design a model of higher education information systems that can identify the performance of higher education institution $s$ in accordance with accreditation requirements that can provide information as soon as possible. This system is designed for college managers to evaluate program achievements in finance and learning processes. The college online executive information system is an information system designed with a waterfall approach where existing features are based on financial information needs, learning processes, lecturer performance, academic performance, students and graduates. The ease of access to information is shown by the ease of access in various places and tools because this system is web-based and accessed with mobile devices.
\end{abstract}

Keywords: Private University, executive information system, online, web base, waterfall approach

\section{Introduction}

Higher education governance is a highly relevant issue of the protection of human rights, democracy and the rule of law. According to the fundamental ideas and assumptions of reform thinking, universities and colleges must be externally controlled, their activities should be formally evaluated, they must be responsible for their performance, they must be controlled by market forces and not by the government or the State. Management must be run by professional leaders and managers. Higher education governance in the 21st century needs to develop a fusion of academic missions and executive capacity, not replace one for the other (Hoffman, 2011). Effective governance is a blend of authority and harmonious authority and a balanced balance of trust and control where democratic, autocratic management styles and laissez faire are handled according to the needs of society and within the limits of the law (Khalid,2016;Sayantani,2015). The development of the era of globalization and the advancement of information technology today has encouraged a high level of competition in the education industry. Therefore, the quality of the education system in Indonesia must continue to be improved, so that the quality of education is increasingly qualified by producing graduates who are able to face the development of that era. Higher education is a continuation of secondary education which is organized to prepare students to become members of the community who have academic and professional abilities that can apply, develop and create science, technology and art. To support the main task of the college, all resources must be managed properly. Resources that can support such as finance that is managed with the help of sophisticated technology will be able to produce accurate information that supports leadership decisions in developing higher education (Jornada, 2005; Hisham, 2014; Sonu, 2016; G Vincent, 2017). 
The law on the national education system stipulates that the management of higher education in Indonesia is possible to be managed by foreign parties. This condition causes intense competition among higher education managers to compete in Indonesia. Several private universities experienced a decrease in interest in quantity which led to financial problems and ended with the closing of the private universities. The quality and relevance to improve the competitiveness of college graduates is a must. The role of universities in preparing the nation's competitiveness through the era of global competition has been very urgent. In general, higher education in underdeveloped countries is even alienated from the needs and realities of social, economic and cultural society. The problem of the quality of higher education is only a symptom that needs careful research to get the root of the problem. Factors related to the quality and relevance of education in universities, related to aspects of the system and resources, both human resources (lecturers and employees), infrastructure, and financial resources (Indiyati, 2015; Khalid, 2016). In managing private universities, there is a trade-off between increasing the number of students, the cost of tuition fees and the quality of education. The lower the quality of education, the lower the number of students and the smaller the financial resources they have. The smaller the financial resources they have, the lower the quality of education of a private university. If this happens, it is feared that it will result in further deterioration of education in private university.

\section{Literature Review}

The effectiveness of organizational management is seen as a success in quality in accordance with the desired expectations. To achieve this success, many parties use information technology tools to produce information (Emad, 2014; Azmi, 2015; Daw, 2015; Deni, 2015). Information and Communication Technology is seen as something that can lift the image of the nation, countries in the world are competing to advance technology, information and communication). Information Technology is a technology used to process data, including processing, obtaining, compiling, storing, manipulating data in various ways to produce quality information, which is relevant, accurate and timely information, which is used for personal, business, and governance and is strategic information for decision making (Nurluoz and Birol, 2011; Allahawiah, Al-Mobaideen and Nawaiseh, 2012; Hawajreh and Sharabati, 2012;Yaser,2014; Vahid and Mohammadrahim, 2015). The effectiveness of information systems can be seen from the nature of the information produced with the characteristics presented at the right time, easily understood, the format is right, consistent and in accordance with needs (Sabherwal,2006; Kamel,2012; Onaolapo, 2012). This is also supported by the results of research which states that the use of information technology will be able to support the effectiveness of business management (Harash, Al-Timimi and Radhi, 2014;Anghooti,2015). Traditionally, the role of higher education institutions has focused on the transfer or conservation of knowledge and is expected to be a community that holds values that are considered ideal or upheld by a nation. He is expected to be a community that is able to protect himself from co-opting environmental values outside which may be corrupt or contain evil. This is what underlies the need for the status of independence or autonomy of universities. In addition, a freedom or independence is also needed to support the realization of innovation or the development of thought and science. Freedom also then touches individuals who are included in the community, because in essence, innovation and thought are not produced by institutions, but individuals within it. One concept that is currently being main stream in the administration of higher education is the concept of good university governance (Fielden, 2008). This concept is actually a derivative of a more general governance concept, namely good governance. Governance is a whole set of decision / policy 
making processes and a whole set of processes where the decision is implemented or not implemented. Good governance requires 8 general / basic characteristics, namely participation, consensus orientation, accountability, transparency, responsiveness, effective and efficient, equity (equality) and inclusiveness, and law enforcement / supremacy.

This research uses qualitative and descriptive approach. The population in this study is one of Private Universities in Cimahi. The method of research was done to achieve the goal of this research is descriptive qualitative method and experimental Method. The development method used in the design of the Private Universities financial information system model is the Linear Sequential Model or Waterfall Development Model approach. The Linear Sequential Model or often called the Waterfall Development Model, is the oldest, most widely used software development paradigm. This model proposes a systematic and sequential software development approach that starts at the level and progress of the system at all stages of analysis, design, code, testing and maintenance.

\section{Results}

Management universities face the competition is very high. If universities want to expand and trusted by the public, of course the managers of universities should strive to be able to solve the problems faced by so high college survive in the competition and generate added value that can be perceived by the stakeholders. For that colleges generally have a standard operating procedure in place to carry out their academic activities. If there is a condition or problem, then the officer is required to perform the instructions contained in the rules and standar operating procedure. Some problems are not contained in the rules and standar operating procedures will require skills and experience of each officer in the finish. In certain circumstances a manager may face the same problems, thus allowing some officers to the field or a different job level involved. In these circumstances, the officer will issue a decision that may be different from each other, depending on its position. During his time, the official will have the knowledge to solve the problem that comes from experience and has developed advanced higher education. When taking decisions, the management need information especially historical information. But often the information is not readily available. When faced with a problem that managers are faced with what the solution should be taken so that these problems can be solved in the not too long. To help managers select or define the solution to the problems. The Online Higher Education Executive Information System (SIEPTO) is a system developed to improve the efficiency and quality of financial information for decision making and as a basis for the submission of higher education accreditation held by National Accreditation Board for Higher Education. SIEPTO supports every process carried out in accreditation such as submission of accreditation proposals by universities. In the SIEPTO system, each manager acts as a user who submits data related to accreditation of both qualitative and quantitative data, especially those that are related to the financial for Higher Education Accreditation, as well as Study Program Accreditation. Every leader or official and also the person who plays a role in collecting academic data, infrastructure facilities and finances will be given 1 (one) account using different username and keywords. The account is used to log in and access different menus according to the role of each user in providing data and information related to finance and accreditation of both college accreditation and study program accreditation within the university. The leadership or chairman account is used to access a dashboard containing a summary of the prediction of accreditation positions based on each assessment determined by the Higher Education. Deputy Chair 1 is given an account that can access menus related to curriculum and research and 
community service. Deputy chair man 2 is given an account that can access menus related to human resources, financing, facilities and infrastructure, and information systems. Next Vice Chair 3 is given an account that can access the menu related to student affairs and graduates. The Chair of the Study Program and Secretary of the Study Program is given an account with access to filling in the qualitative accreditation forms and curriculum along with student affairs. The Head of Administration is given access to input regarding facilities and infrastructure and finance. The Chairman of the Research Office is given an account to access menus related to research, community service and Patents or Intellectual Property Rights obtained by each Study Program.

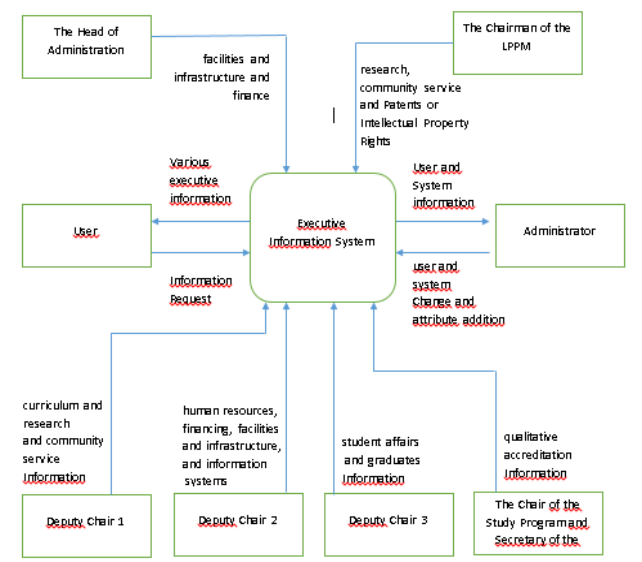

Fig.1. Flow chart of context diagram in the SIEPTO

Outputs from SIEPTO can be used by university leaders to evaluate the achievement of program implementation in terms of both the budget and the learning process. With the existence of this system, the leader can make improvements to the process that has not achieved the goals and expectations.

\section{Conclusions}

The management of higher education must be done in a good way in order to compete in producing quality graduates. To assist leaders in monitoring the management performance of universities, a web-based executive information system is designed to be adapted to accreditation needs. With this SIEPTO, the leadership is facilitated in obtaining information as soon as possible, so that decisions taken are up to date and appropriate.

\section{Reference}

[1] Anghooti Vahid \& Najafzadeh Mohammadrahim, 2015, The Relationship Between Information Technology And Knowledge Management And The Productivity Of Managers And Employees In Youth And Sports Departments Of East Azerbaijan Province, Indian Journal of Fundamental and Applied Life Sciences ISSN: 2231- 6345 (Online) An Open Access, Online International Journal Available at www.cibtech.org/sp.ed/jls/2015/01/jls.htm 2015 Vol.5 (S1), pp. 2027-2032

[2] Allahawiah, S., Al-Mobaideen, H. and Nawaiseh, K. al,2012, The Impact of 
Information Technology on Knowledge Management Processes - An Empirical Study in the Arab Potash Company', International Business Research, 6(1), pp. 235-252. doi: 10.5539/ibr.v6n1p235.

[3] Azmi Fitriati \& Sri Mulyani, 2015, Factors Tahat Affect Accounting Information System Success and Its Implication On Accounting Information Quality, Asia Journal Of Information Technologi 14 (5) : pp 154-161

[4] Daw Hla \& Susan Peter Teru, 2015, Efficiency of Accounting Information System and Performance Measures - Literature Review, International Journal of Multidisciplinary and Current research, Vol.3, pp 976-984

[5] Deni Iskandar, 2015, Analysis Of Factors Affecting The Success Of The Application Of Accounting Information System International Journal Of Scientidic \& Technology Rsesearch Volume 4, Issue 02: pp 156-163

[6] Emad Harash,Suhail Al-Timimi \& Ahmed Hussein Radhi, 2014, The Influence of Accounting Information Systems (AIS) on Performance of Small and Medium Enterprises (SMEs) in Iraq, Journal of Business \& Management,Volume 3, Issue 4 , pp 48-57

[7] Florian Hoffmann, 2011, Good Governance in Higher Education: Concepts, Implementation and Training, Dies Conference Strengthening Universities, Enhancing Capacities - Higher Education Management for Development. Bonn, 28-29 November, 2011

[8] G. Vincent,2017, Implementing ERP in Higher Educational Institutions, International Journal of IT, Engineering and Applied Sciences Research (IJIEASR) Volume 6, No. 1, pp. 17-20

[9] Harash, E., Al-Timimi, S. and Radhi, A. H.,2014, The Influence of Accounting Information Systems (AIS) on Performance of Small and Medium Enterprises (SMEs) in Iraq', Journal of Business and Management, 3(4), pp. 48-57. doi: 10.12735/jbm.v3i4p48.

[10] Hawajreh, K. M. and Sharabati, A.-A. A,2012,The Impact of Information Technology on Knowledge Management Practices', International Journal of Business, Humanities and Technology Technology, 2(7), pp. 102-107. doi: 10.5539/ibr.v6n1p235.

[11] Hisham Al-Mobaideen, Sattam Allahawiah \& Abeer alkhawaldeh, 2014, Factors Influencing The Effectiveness Of E-Learning Systems In The Educational Process ("Electronic Learning System") (Eduwave): Jordan Case Study, European Scientific Journal December edition vol.8, No.28, pp 1-21

[12] Indiyati,Dian and Nuyman Amir,2015, A Knowledge Management Behavior in Private Colleges. Review Of Integrative Business \& Economics Research Vol 4 (2) pp 199 207

[13] John Fielden, 2008,Global Trends University Governance, World Bank.

[14] Kamel Mohamad Hawajreh \& Abdel-Aziz Ahmad Sharabati, 2012, The Impact of Information Technology on Knowledge Management Practices, International Journal of Business, Humanities and Technology Vol. 2 No. 7; pp 103-107

[15] Khalid Zaman, 2016, Quality guidelines for good governance in higher education across the globe, Pacific Science Review B: Humanities and Social Sciences 1;pp 1- 7

[16] Leo Jornada \& Tamara Beltok, 2005, Implementing ERP Systems in Higher Education Institutions, 27th Int. Conf. Information Technology Interfaces ITI 2005, June 20-23

[17] Nurluoz, Ö. and Birol, C.,2011,The impact of knowledge management and technology: An analysis of administrative behaviours', Turkish Online Journal of Educational Technology, 10(1), pp. 202-208. doi: 10.1016/j.mcm.2005.07.004. 
[18] Onaolapo A. \& Odetayo T., 2012, Effect of Accounting Information System on Organisational Effectiveness: A Case Study of Selected Construction Companies in Ibadan, Nigeria, American Journal of Business and Management, Vol. 1, No. 4: pp 183-189

[19] Sabherwal, R., Jeyaraj, A. \& Chowa C., 2006, Information System Success: Individual and Organizational Determinants. Management Science. 52(12): pp 1849-1864.

[20] Sayantani Goshi, \& Nilandri, 2015, Effective Implementation of performance management in higher educational institutions (HEI), Journal of Scientific Research and Development 2 (11): pp 17-21,

[21] Sonu Rani,2016, A Review of ERP Implementation in Higher Education Institutions, International Journal of Advanced Research in Computer Science and Software Engineering Volume 6, Issue 6, pp.542-545,

[22] Vahid, A. and Mohammadrahim, N.,2015, The Relationship Between Information Technology and Knowledge Management and the Productivity of Managers and Employees in Youth and Sports Departments of East Azerbaijan Province', Indian Journal of Fundamental and Applied Life Sciences, 5(S1), pp. 2027-2032.

[23] Yaser Hasan Al-Mamary, Alina Shamsuddin, \& Nor Aziati, 2014,Factors Affecting Successful Adoption of Management Information Systems in Organizations towards Enhancing Organizational Performance, American Journal of Systems and Software Vol. 2, No. 5, pp 121-126 